Ricardo Sosa *

\title{
Designerly \\ Research and \\ Researcherly \\ Design Skills, \\ Mindsets, and \\ Methods for \\ Revolutionary \\ Practices
}

Ricardo Sosa is Associate Professor at Auckland University of Technology and Adjunct Associate Professor at Monash University. He teaches and conducts research in design with an emphasis on creative and critical technologies. His early work introduced the use of computational social simulations to study the societal dimensions of design creativity and innovation. He now collaborates with specialists from across areas and with local communities to enact ethical social impact through innovative and responsible approaches to technology. He strives to uphold the obligations in the Treaty of Waitangi in Aotearoa New Zealand. <ricardo.sosa@aut.ac.nz > ORCID: 0000-0002-3678-0702
Abstract This paper builds on the complementary identities of a 'researcherly designer' as a person who informs their design practice with research and a 'designerly researcher' as a person who informs their design practice with research and a 'designerly researcher' as a person who informs their research practice with design. Here, I ex-tend and examine this reductive duality paying close attention to the skills, mindsets, methods, and practices in design and research. I argue that when the skills, tools, techniques, and methods normally used in design activity are used in research activ-ity, clear distinctions need to be articulated on the purposes and contexts of their use. Individuals who are in the position to execute roles as different as design and research can be considered to be 'ambidextrous' or 'revolutionary' as they have the potential to cultivate disruptive synergies between these worlds. The paper addresses the rich diversity, the opportunities and risks, and the ethical tensions that come from 'chang-ing hats' between design and research established practices, and the 'queer' uses of methods in such interstices. I draw from earlier work on the creative adaptation of design methods for crossdisciplinary research (Sosa \& Grocott, 2020). The paper con-cludes with generative questions for those who embark onto the emerging revolution-ary practices between design and research.

Keywords Research methods, Queer uses, Non-Traditional Research Outputs, Design metod 


\section{Habilidades, mentalidades e métodos de design de pesquisa e design para práticas revolucionárias}

Resumo Este artigo baseia-se nas identidades complementares de um "designer pesquisador" como uma pessoa que informa sua prática de design com pesquisa e um "pesquisador designer" como uma pessoa que informa sua prática de pesquisa com design. Aqui, eu estendo e examino essa dualidade redutiva, prestando muita atenção às habilidades, mentalidades, métodos e práticas em design e pesquisa. Eu defendo que quando as habilidades, ferramentas, técnicas e métodos normalmente usados na atividade de design são usados na atividade de pesquisa, distinções claras precisam ser articuladas nos propósitos e contextos de seu uso. Indivíduos que estão em posição de executar funções tão diferentes quanto design e pesquisa podem ser considerados "ambidestros" ou "revolucionários", pois têm o potencial de cultivar sinergias disruptivas entre esses mundos. 0 artigo aborda a rica diversidade, as oportunidades e riscos, e as tensões éticas que vêm da 'mudança de chapéus' entre as práticas estabelecidas de design e pesquisa e os usos 'queer' de métodos em tais interstícios. Eu me baseio em trabalhos anteriores sobre a adaptação criativa de métodos de design para pesquisas interdisciplinares (Sosa \& Grocott, 2020). 0 artigo conclui com questões geradoras para aqueles que embarcam nas práticas revolucionárias emergentes entre design e pesquisa.

Palavras chave Métodos de pesquisa, usos queer, resultados de pesquisa não tradicionais, métodos de design 


\section{Habilidades de diseño, mentalidades y métodos de investigación y diseño para prácticas revolucionarias}

Resumen Este artículo se basa en las identidades complementarias de un "diseñador investigador" como una persona que informa su práctica de diseño con la investigación y un "investigador de diseño" como una persona que informa su práctica de investigación con el diseño. Aquí, extiendo y examino esta dualidad reductiva prestando mucha atención a las habilidades, mentalidades, métodos y prácticas en el diseño y la investigación. Sostengo que cuando las habilidades, herramientas, técnicas y métodos normalmente utilizados en la actividad de diseño se utilizan en la actividad de investigación, es necesario articular distinciones claras sobre los propósitos $y$ contextos de su uso. Las personas que están en condiciones de ejecutar roles tan diferentes como el diseño y la investigación pueden considerarse "ambidiestros" o "revolucionarios", ya que tienen el potencial de cultivar sinergias disruptivas entre estos mundos. El documento aborda la rica diversidad, las oportunidades y riesgos, $y$ las tensiones éticas que surgen de "cambiar de sombrero" entre las prácticas establecidas de diseño e investigación, y los usos "queer" de los métodos en tales intersticios. Me baso en trabajos anteriores sobre la adaptación creativa de métodos de diseño para la investigación interdisciplinaria (Sosa \& Grocott, 2020). El artículo concluye con preguntas generativas para quienes se embarcan en las prácticas revolucionarias emergentes entre el diseño y la investigación

Palabras claveMétodos de investigación, Usos queer, Resultados de investigación no tradicionales, Métodos de diseño 


\section{Introduction}

Design and research as professional activities have become complementary in the first two decades of the twenty-first century. On the one hand, professional design increasingly draws from an ever-expanding corpus of evidence and insights from research activity. On the other, higher education policies have compelled design academics to upskill and undertake advanced research activity. The forces that bring together design and research have resulted in professional design gaining in scope, impact, and recognition (Gold, 2007; Telenko et al., 2016) while research has gained in conceptual and methodological innovation (Sosa \& Grocott, 2020; Stappers, 2007). However, the tensions and challenges created by bringing these two significantly different activities are far from trivial and are only gradually being better understood. More work needs to be done to support practitioners who navigate the confluence of the rough waters of research and design. Beyond the designer/researcher binarism, this paper acknowledges a plurality of activities and identities that combine design and research, and it aims to contribute to the discussion and recommendations for design researchers, design practitioners, and the diverse space in between.

More opportunities for innovation occur in interstitial or intersecting spaces. Such spaces can also be chaotic and confusing, as the meaning and implications of new combinations and possibilities emerge. In the interstice between design and research, tensions become more visible starting with their own significant diversities. Design, on the one hand, spans across artistic, technical, and societal overlaps with other specialties. Research similarly varies in considerable ways across disciplinary and methodological traditions. How, then, can those who engage in design as well as research, make sense in such variable worlds to connect, complement, and integrate work across their design and research activities? Several voices have contributed to the academic discussion spanning from definitions of research into/for/through design (Frayling, 1994) to the various formulations of practice and research approaches (Vaughan, 2017; Zimmerman \& Forlizzi, 2008).

The work presented here stems from the general question: "How do the varied modes of practice and research in design areas relate to each other?". Engaging with this question, the goal is to identify ways to apply, adapt, and transform a plurality of practices from design areas for the purpose of research. As a point of departure, I select an excerpt from a prominent practice-led research author that articulates the notion that the methods that are familiar to designers can stand as research methods -while noting the need to validate and discipline said methods. 


\begin{abstract}
...in practice-led research 'the research strategy is carried out through practice, using predominantly methodologies and specific methods familiar to us as practitioners' (Gray 1996: 3). This is a radical and bold innovation, for it not only affirms the primacy of practice in the research process, but it proclaims that the techniques and tools used by the practitioner can stand as research methods in their own right. This places considerable power with the practice-led researcher. Certainly, it means there is a need to identify and validate existing methods of practice (and perhaps even discipline them somewhat), but it is these methods, specific to practitioners, that become the spine of the research process. Acknowledging and validating them means that practice-led researchers don't always have to turn to the arsenal of methods from other traditions in order to justify their research. (Haseman, 2007).
\end{abstract}

This line of reasoning is of interest not only for articulating the claim that familiar methods used for design practice can stand as research methods, but also for the implication that doing so liberates design researchers from using methods from other traditions to justify what they do. Here I argue that just as design researchers need not uncritically turn to other research traditions to justify their work, they equally need not uncritically turn to design practice for the same purposes. Instead, I interpret the call for disciplining design methods for research as an opportunity for methodological innovation (Kara, 2015). My core assumption in doing this is that the creativity that designers display can be oriented to develop innovative approaches to modes of research that are most appropriate to our work without having to unimaginatively turn to established research or practice traditions.

Previous work has shown how design methods, through careful repurposing and intentional application, can be imaginatively adapted and fruitfully contribute to methodological innovation (Sosa \& Grocott, 2020). This paper extends that idea to suggest ways in which design practitioners are able to combine design and research practices to decolonize, emancipate, and tackle complex societal challenges through a myriad possibilities between researcherly design and designerly research (Yee, 2017). The paper continues with a critical perspective on the meaning and use of methods to contextualize their paradoxical connections. 


\section{Methods Across Contexts}

Methods in design have transitioned through stages ranging from reductive and prescriptive formulations some decades ago, all the way to the current proliferation of toolkits. Multiple voices persuasively push back against the constraints imposed by methods in design, yet their pedagogical value is difficult to underestimate. These days, a widely-accepted version of design methods encompasses tools, techniques, and heuristics used in teaching and practice (Kumar, 2013) and facilitation (Slocum, 2003).

Methods in research are given significantly higher prominence than in design. Research communities are normally defined around their allegiance to a subset of research methods aligned with a specific epistemological stance. Most graduate programs include mandatory training in methodologies, and across many research cultures, methods are constitutive to the planning, execution and evaluation of research activity. In research (as in design), methodological innovation has been recognized both as necessary and inevitable (Kara, 2015). Design research can be considered multi-paradigmatic and opportunistic, and thus methodological traditions from across all research cultures coexist in design research (Beck \& Stolterman, 2016).

The space between well-established activities includes vast areas for diversity and creative action. Designers carry out informal research practices and researchers carry out informal design practices. By the former we mean those primarily occupied in design activity who intuitively conduct a review of historical precedents or who unsystematically apply some measurements using a prototype or ad-hoc instruments such as surveys or interviews. Such informal research activities are in service of gaining insights for their design activity and are not carried out to claim a direct contribution to the knowledge base of the field except through their role in loosely informing the final design product. An example is the way in which smartphone designers built a prototype game to identify the ideal size of on-screen keyboard buttons (Kocienda, 2018).

By the latter we mean those primarily occupied in research activity who intuitively make design decisions such as the design of stimuli used in experimental studies or the choice of materials used in participatory activities. Such informal design activities are in service of conducting data collection or analysis in a study and make no claims of contributing to the field of design. An example is the way in which psychology researchers chose three-dimensional shapes as building blocks for the systematic assessment of mental imagery (Finke, 1996).

When designers use research to inform their creative decisions, academic rigor is not a priority and when researchers use design to plan their study materials, design quality is not their concern. Hence, the two intersections sketched above can be characterized as 'informal research for design' and 'informal design for research', respectively. These extend to 
include formal collaborations or integrations, i.e., those formally trained in both design and research (Yee, 2017) corresponding to the standard categories of research into, through, and for design (Frayling, 1994).

Another area where methods intersect is that between design and research in the Humanities, which includes a set of approaches to knowledge based on analysis and argumentation, whether historical, textual, or conceptual. There, the designers of "propositional artefacts" explicitly avoid claiming "strong connotations of systematic method" but see their design practice as a "mode of discovery" that "tends to defy systematization" but which "can be a powerful way of probing, developing, and illustrating ideas and arguments" (Walker, 2013). In situating the application of design skills in research activity, Walker further clarifies:

As an element of a research methodology whose purpose is primarily exploratory and conceptual, the activity of designing should be regarded less as a problem-solving activity and more as a question-asking activity. (...) The resulting artifacts, which are effectively questions-in-form, exist within a continual process of exploration, debate, and knowledge development. To include designing as a bona fide constituent of an academic research methodology, we must be clear about its purpose, its mode of progression, and its potential contribution within a comprehensive research process. (Walker, 2013)

The framing of this combination of design and research once again alludes to the legitimacy of design (as "a bona fide constituent") in research activity. Moreover, in the placement of propositional artefacts, professional design practice is clearly differentiated from an academic form of design practice:

It becomes clear that the role of the propositional object within academic design research can be quite different from that which we normally associate with product design. (...) propositional objects explore and express theoretical ideas within an academic research agenda; this is a form of fundamental or pure design research rather than applied. (Walker, 2013)

To conclude this background analysis of methods, we return to the question of whether it is reasonable to expect that the type of design activity observed in professional practice can stand as research activity in its own right. Considering that the purposes of design activity and the role of the designed artefacts change so notably between these two contexts, it seems reasonable to infer that design methods change when used for research. Acknowledging the limitations of methods both in design (Agid \& Akama, 2020) and in research (St. Pierre, 2021) does not entail that they are not a significant part of practice and, again, that they play important roles including as pedagogical tools. 
In all, discussions about methods are far from consensual. Individuals as well as communities have their own preferred practices, habits, and terminologies. This is evidenced by how different designers name, use, and talk about their methods (Pei et al., 2011). Hence, conversations about the ways in which design and research methods relate need to avoid casting a reductive definition of what methods are. In this work, we pay attention to the ways in which seasoned practitioners talk about them, including professional designers, expert academic researchers, and everyone working in between these two extremes.

\section{Designerly Research and Researcherly Design Revolutionary Identities}

The concept of normal science can be useful to examine the two polar extremes constituted by design and research activities within paradigms that are certified by established communities (Kuhn, 1996). In contrast, revolutionary phases of transformation can occur as the result of crises where anomalies cannot be adequately addressed within an established paradigm. I argue here that the interstices between those who inform their normal design practice by/through formal research practices and those who inform their normal research practice by/through formal design practices can be better understood as nebulous pre-paradigmatic spaces that are neither here nor there. As such, they need not be justified or reified neither as professional design practice nor as academic research practice. The revolutionary practices that emerge in these interstices escape binarism.

Interstices provide shelter to emerging practices for those who choose not to adopt a scientific/social/humanities/artistic academic tradition to inform their design practice. They also provide fertile ground to those who choose not to dress up their design practice as research. Rather, these individuals and their emerging communities find intellectual excitement, unexplored opportunities for impact, and merit in the transformation of normal practices to explore revolutionary modes of integrating design and research.

The ways in which the status quo in academia discourages revolutionary practices are well documented. Such inhibition of disobedient spaces perversely causes a dissociation between how a designer sees her creative practice and what she must say out loud and write in performance reports and in applications for funding and scholarships. The design researcher ends up thus facing a binary choice about her identity: she is made to choose to be recognized either as a designer or as a researcher to justify the value or appropriateness of her work. Her creative artefacts often end up being evaluated under hostile academic regimes and her efforts spent on justifying her place in the academe. Such perversity begins the moment a graduate student starts her research journey: either by her choice of 
School or Department where she enrolls, or by explicitly being required to tick a box to indicate whether her thesis will be a traditional manuscript or a "creative artefact, exegesis, and exhibition". The distortions created by this binarism include that many designers end up in a position of having to check their design expertise at the door, or to disguise it as academic research. Other ways are possible, and they are explored in the remaining of this paper.

To illustrate normal and revolutionary practices, three vignettes are presented here: the first to highlight how design practitioners talk about their work amongst their peers; the second to highlight how the work of design researchers is evaluated in academia; and the third to illustrate the vast and rich possibilities beyond these two extremes. The vignette method used to create these cases applies a priori reasoning (Kitcher, 2000) in a process of creative synthesis informed by cases and sources that are well documented and accessible to the public, rather than by data collected purposely and analyzed by researchers behind the scenes.

The first vignette synthesizes the way methods are used by design practitioners as they recount their work in keynote presentations at specialist guild events such as the Design Indaba Conference ${ }^{1}$. The topics, nature, and length of these presentations vary but they normally include specific references to professional design projects of prominence led by the presenter. Exemplary presentations in this category include those by Alex Chen, Jen Bilik, Michael Bierut, and Christine Goudie ${ }^{2}$. When these professionals talk about their craft, we can infer their use of design methods in professional contexts. As listed and illustrated in Figure 1, this use methods is primarily to address a problem and with the intention to generate new solutions. For the professional designer, results take priority over process. When they talk about their work, they emphasize what they got out of the process rather than how they got it. They take pride on results that were unexpected or to some extent surprising to the market. The professional use of design methods is of a highly instrumental nature, they select methods in ad-hoc ways and for a specific purpose. The use of methods by professionals is often opaque, there is no need to justify the choice of methods or the correctness of use. This type of usage is highly contextual, as no-one would expect the same design method to produce the same results if applied by other designers or in a different project. Lastly, the time scale in design projects is days to weeks, and the ultimate test of whether a method was appropriate, useful, and applied adequately is defined by the performance of the designed solution, normally by commercial success, critics' review, or by the funding body (Hanington, 2003; Laurel, 2003). Crucially, design communities are not defined by their methods -the type of designed artefacts is what defines design communities: graphic, industrial, interaction design, etc. 
Fig 1. Vignette of the professional use of design methods

"We decided to make it feel
personal and fun instead of doing
corporate identity... so I painted
the word over and over and over
again until it started to look funny
after a while; I did a whole
alphabet" (6:30) Michael Beirut

The second vignette shown in Figure 2 captures the ways in which design researchers use design methods as inferred from how they are required to present their work in academia. The sources for this vignette include Appendix 2 "Criteria for assessing PhD work" in (Gray \& Malins, 2016) and presentations by design researchers in academic conferences such as those by P. Malasan; S. Thakurata and P. Banerjee; and Alexandra Alden at PIVOT $2020^{3}$. The academic use of design methods radically differs from their professional use. First, methods are used to address research questions with the intent to generate or test knowledge. In research contexts, the process is an important measure of the results or outcome. In other words, how the researcher got those results is as critical as the results themselves. There is a strong expectation of systematicity of process in research, whether this is about replicability, validity, or authenticity depending on the epistemological commitments. In most if not all research, the use of methods is transparent, and readers expect this type of use to be persuasively justified and clearly communicated independently of the outcomes. In research, methods are transferable -though what this means depends on the methodology. However contextual, the methods are expected to be applied to a certain standard across studies. In research, all methods are subject to institutional review mechanisms for accountability, ethics, and risk management. Lastly, methods in research are normally used on a time scale of weeks to months or years and the ultimate test is decided by those in the position of gatekeeping a community of peers. Crucially, research communities are formed around a field or topic of study as well as a specific subset of research methods validated and invigilated by the field's experts. 
Fig 2. Vignette of the academic use of design methods

"We designed a three-week
program that took participants
from learners to leaders and we
did that through... the first part
was focus on teaching the design
process and the design tools"
(3:50) A. Alden
"Use a range of standard and
specialized instruments, tools,
methods, and techniques of
enquiry" (Gray \& Malins, 2016,
p.188)
"Discussions are mediated by tools,
for example mood boards are
used to discuss 'ambience' of
designs and target markets...
After meetings, targets were
written in a 'design progress
sheet' to monitor the progress"
(8:50) P. Malasan

The third vignette in Figure 3 maps the vast space of possibilities in between the normal professional and the normal research spheres. It is informed primarily by the work of PhD alumni and students in the Creative Technologies program at AUT University in Aotearoa, New Zealand. Antonio Esparza built on personal entrepreneurial experiences in design to study the use of additive manufacturing for "entrepreneurial ideation", a term that captures the process of creatively imagining new products and the type of companies to take them to market (Esparza, 2020). Miranda Verswijvelen draws from a long and successful career in e-learning and narrative game design to systematically study the creative uses of interactive narrative techniques to support training in compassionate care (Verswijvelen et al., 2020). Miguel Montiel applies his professional product design expertise to study the ways people interact with everyday artefacts and the discourses that shape these interactions with the intent to expand "design for sustainability" beyond individual artefacts towards a systems level of actor-network interaction (Montiel et al., 2020). Lastly, Parisa Moradi applies her professional design skills to design the user experience of participants in an ethnographic study and to translate her findings into guidelines for designers of smart products (Moradi et al., 2019).

In their journeys from design to research, these students bring their professional strengths to inform, enrich, and extend their research projects. They avoid the ultimatum of having to adhere to established research traditions, whether in artistic, social, natural science or other modes of inquiry. Instead, they place their design sensibilities at the center of their 
$\mathrm{PhD}$ projects to continuously engage with the question: How does my design practice shape my research, and vice-versa? In all cases, they manage to meet the criteria set by inter-disciplinary research standards and they also transform their design practices informed by their research experiences. The quotes in Figure 3 illustrate how their design sensibilities shape every stage from crafting a research question, to the nature of their literature reviews; from the alignment with and 'hacking' of research methods to the design of a study; from their data collection and analysis approaches to the applicability of their findings.

As these students learn the normal uses of research methods, they creatively and resourcefully integrate and complement these with the design methods that they have advanced mastery on. This way, they use methods that can be characterized somewhere between designerly-research and researcherly-design methods to reveal new problems and questions, and to examine ideas, knowledge, and meanings. Their use of methods shows that the gaps between process and results are blurred, and unanticipated questions and outcomes are welcome. Their approaches show that instrumental and haphazard uses of methods become complementary throughout a project. Some uses of methods are opaque, others more transparent uses -in ways that resemble the distinction between autographic to allographic media, with the former being created with a personal intent and the latter to be reproducible and shared (Goodman, 1976). The ways methods are used in this vignette range from particular to transferable and from applicable to pre-anticipatory. Lastly, the time scale can reach from days to months and their ultimate assessment includes by self, by peers, and by the market.

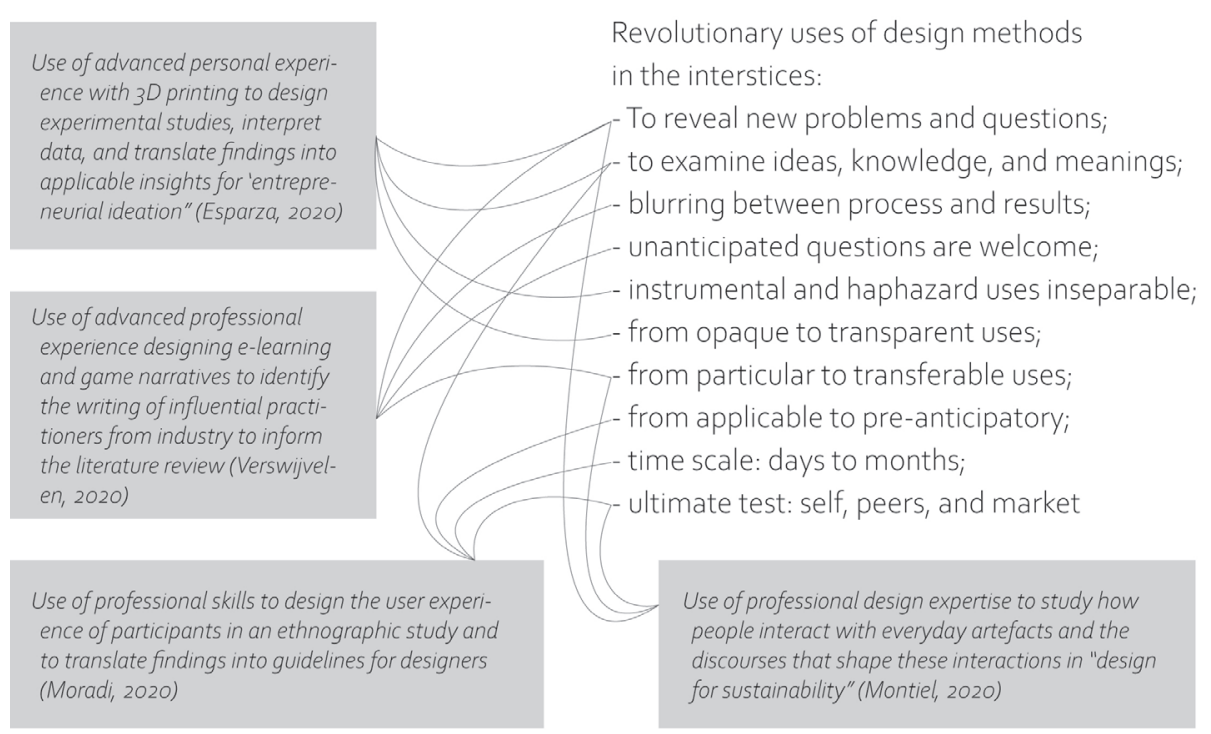

Fig 3. Vignette of the revolutionary uses of design methods in the interstices 
Admittedly, a limitation of this work is that the third vignette is not as sharply defined as the first two, which are more prescriptive and well established. The third vignette points towards an inclusive space and it can be said to include "queer uses" of methods, following Sarah Ahmed (2019). By "queer uses" Ahmed refers to the ways in which things are used "for purposes other than the ones for which they were intended" and "by those for whom it was not intended" (Ahmed, 2019). Ultimately, by presenting these three vignettes and highlighting the queerness of emerging, revolutionary practices between design and research, we join those who propose imaginative responses against the normativity and the "methodolatry" of disciplined research traditions (Law, 2004).

\section{Implications for Revolutionary Practices}

The first consequence of naming alternative uses of design and research methods is conceptual clarity. Today silos exist separated by exclusionary walls: "PhD by Design", "Practice-led/based/oriented", "Research through Design", "Design Science", etc. These segregated communities coalesce by their allegiance to a subset of possibilities between the normal worlds of design and research. By acknowledging the creative interstices between these poles of normativity, new PhD programs and academic spaces can be imagined where methodological innovation is celebrated. The definitions of Non-Traditional Research Outputs and quality criteria can help these inclusive spaces break away from either counting traditional journal papers or traditional design artefacts as metrics of research impact.

Supervisors of $\mathrm{PhD}$ projects would need to become more open-minded, flexible, and comfortable in roles of non-experts, and keener to co-supervise $\mathrm{PhD}$ research with specialists from other methodological cultures including from outside academia. Most of the PhD students in Creative Technologies at AUT University are indeed co-supervised between people of different backgrounds and affiliations who continuously learn methodological possibilities from each other and together. When it comes to the $\mathrm{PhD}$ thesis, these students formulate personal strategies around formats which go beyond the traditional manuscript or the traditional exhibition plus exegesis. For example, some of them have chosen to dedicate a chapter of their thesis to first-person creative practices and how these contribute to their research project. Examiners tend to appreciate the value of linking this meaningful personal creative engagement with the research methodologies in the thesis.

The revolutionary uses of methods advocated for in this paper also open new opportunities for skill development and the creation of new languages and tools to support other ways of knowing. This is consistent with anti-colonial agendas both in industry and academia, and supports 
plurality as a constitutive value (de Sousa Santos, 2014). A further implication of this is to re-imagine what and how is taught in graduate courses of Research Methods. In most cases, these are limited to specific disciplinary traditions, and it is unusual for $\mathrm{PhD}$ students to be exposed to methods from across research cultures. In addition to expanding the curriculum to include a diversity of established research methods, in inter-disciplinary design areas such courses would need to consider how to create opportunities for students to build upon their mastery of design methods to augment their research. One answer to this challenge to be elaborated in future work is in the framing of 'generative themes' as suggested by Paulo Freire (2000) for emancipatory education.

\section{Conclusions}

The work presented here is motivated by the observation that "knowledge, experience, and skills from almost any arena can make a useful contribution to research" (Kara, 2015). Thus far designers engaging with research have yet to make substantial contributions to research methods, other than following tropes from artistic research traditions that do little more than argue for practice-as-research. We seek to contribute to the conversation around how design contributes to research (Stappers, 2007) by sharing how research activity can make use of creative reframings of purpose, question, and methods.

The main purpose here has been to offer an argumentation for people who are in different trajectories but meet in between the conventional design and research areas. It is our aim to invite them to think beyond binarism and to reject the reductive choice to conform as designers or as researchers. The vast space between these extremes is queer, revolutionary, and exciting. We close the paper with a list of generative questions to open conversations for change based on the work of Senge et al. (2008):

- Rather than advocate for or oppose certain methods or their uses, what are genuine questions that people can consider that lead them to fresh perspectives and new possibilities?

- How can people recognise that no-one has the full picture and that we all see a slice of the possible uses of methods?

- Who are the like-minded people who are seeking to make a case for change and the inclusive spaces where these concerns are shared? 
- What is the common ground and what are the larger visions and goals for those seeking methodological innovation in your area?

- How may people define criteria of quality in their queer uses of methods?

- How can people acknowledge disagreement and dissent that are characteristic of pre-paradigmatic spaces whilst building dialogue and inclusiveness?

- What are the system dynamics and structural barriers to methodological innovation in your area?

- Methodological innovation is a collective effort, how might you go about engaging those excluded?

- How can we shift conversations from the problems and limitations of existing methods and their uses towards the possibilities of queer uses?

- What are the ethical risks, blind spots, and unintended consequences of queering the uses of design and research methods in your area?

\footnotetext{
1 Design Indaba Conferenecs: https://www.designindaba.com/conference-talks

2 https://www.youtube.com/playlist?list=PLN16dYaobiEXtAP5jbPZYyMtfZk50j_9g

3 https://www.youtube.com/playlist?list=PLVil8PnkWaDq06U52a-_P5hGXPWK7c9MZ
}

\section{References}

Agid, S., \& Akama, Y. (2020). Reflexive account-giving through 'practice notations': plural dimensions and dynamics of infrastructuring. Proceedings of the 16th Participatory Design Conference 2020-Participation (s) Otherwise-Volume 2, Ahmed, S. (2019). What's the Use?: On the Uses of Use. Duke University Press. Beck, J., \& Stolterman, E. (2016). Examining the types of knowledge claims made in design research. She Ji: The Journal of Design, Economics, and Innovation, 2(3), 199-214. de Sousa Santos, B. (2014). Epistemologies of the South: justice against epistemicide. Paradigm Publishers. 
Esparza, A. (2020). Entrepreneurship With Additive Manufacturing: Implications of Complexity Freedom in Product and Firm Ideation AUT University]. Auckland. http://hdl.handle. net/10292/13125

Finke, R. A. (1996, 1996/09/01/). Imagery, Creativity, and Emergent Structure. Consciousness and Cognition, 5(3), 381-393. https://doi.org/10.1006/ccog.1996.0024

Frayling, C. (1994). Research in art and design (Royal College of Art Research Papers, Issue. Freire, P. (2000). Pedagogy of the oppressed. Continuum.

Gold, R. (2007). The plenitude: Creativity, innovation, and making stuff. Mit Press.

Goodman, N. (1976). Languages of Art, an Approach to a Theory of Symbols. Hackett.

Gray, C., \& Malins, J. (2016). Visualizing research: A guide to the research process in art and design. Routledge.

Hanington, B. (2003). Methods in the making: A perspective on the state of human research in design. Design Issues, 19(4), 9-18.

Haseman, B. (2007). Rupture and recognition: Identifying the performative research paradigm. In E. Barrett \& B. Bolt (Eds.), Practice as research: Approaches to creative arts enquiry (pp. 147-157). Tauris, I.B.

Kara, H. (2015). Creative Research Methods in the Social Sciences: A Practical Guide. Policy Press.

Kitcher, P. (2000). A priori knowledge revisited. In P. Boghossian \& C. Peacocke (Eds.), New Essays on the A Priori (pp. 65-91). Clarendon Press.

Kocienda, K. (2018). Creative Selection: Inside Apple's design process. Macmillan.

Kuhn, T. S. (1996). The structure of scientific revolutions. Chicago, Ill. : University of Chicago Press, 1996.

Kumar, V. (2013). 101 Design Methods: A Structured Approach for Driving Innovation in your Organization. Wiley.

Laurel, B. (2003). Design research: Methods and perspectives. MIT press.

Law, J. (2004). After Method: Mess in Social Science Research. Routledge.

Montiel, M., Sosa Medina, R., \& Hocking, D. (2020). Activity Scenario Modelling: an emerging method for examining human-artefact interaction. Synergy - DRS International Conference 2020,, Online.

Moradi, P., Hunting, A., \& Sosa Medina, R. (2019, 2019/11/21/). A UX Pedagogy on Multimodal Aspects of Emotions. Fifth International Conference for Design Education Researchers, Ankara.

Pei, E., Campbell, I., \& Evans, M. (2011). A taxonomic classification of visual design representations used by industrial designers and engineering designers. The Design Journal, 14(1), 64-91.

Senge, P. M., Smith, B., Kruschwitz, N., Laur, J., \& Schley, S. (2008). The necessary revolution: How individuals and organizations are working together to create a sustainable world. Currency.

Slocum, N. (2003). Participatory Methods Toolkit: A Practitioner's Manual. United Nations University. 
Sosa, R., \& Grocott, L. (2020). The creative translation of design methods into social research contexts. In H. Kara \& S. Khoo (Eds.), Researching in the Age of COVID-19 Vol 3: Volume III: Creativity and Ethics (Vol. 3, pp. 9-19). Policy Press.

St. Pierre, E. A. (2021). Post qualitative inquiry, the refusal of method, and the risk of the new. Qualitative Inquiry, 27(1), 3-9.

Stappers, P. J. (2007). Doing design as a part of doing research. In Design research now (pp. 81-91). Springer.

Telenko, C., Sosa, R., \& Wood, K. L. (2016). Changing conversations and perceptions: The research and practice of design science. In C. A. \& L. U. (Eds.), Impact of Design Research on Industrial Practice (pp. 281-309). Springer. https://doi.org/https://doi.org/10.1007/978-3319-19449-3_19

Vaughan, L. (2017). Practice-based Design Research. Bloomsbury Publishing. Verswijvelen, M., Sosa, R., \& Martini, N. (2020, August 2020). Designing game-inspired narratives for learning. Synergy - DRS International Conference 2020, Online.

Walker, S. (2013). Imagination's promise: Practice-based design research for sustainability. In The handbook of design for sustainability (pp. 446-465). Bloomsbury Academic.

Yee, J. (2017). The researcherly designer/the designerly researcher. In L. Vaughan (Ed.), Practice-based Design Research (pp. 155). Bloomsbury Academic.

Zimmerman, J., \& Forlizzi, J. (2008). The role of design artifacts in design theory construction. Artifact: Journal of Design Practice, 2(1), 41-45. 